\title{
Manganese Uptake and Accumulation in the Human Brain
}

$\mathbf{S}$ udarshana et $\mathrm{al}^{1}$ are to be commended for their meticulous study of potential brain MR imaging in humans with use of mangafodipir (Mn dipyridoxyl diphosphate [MnDPDP]) as a contrast agent. MnDPDP is a multifunctional chelate releasing calcium-stalking paramagnetic $\mathrm{Mn}$ ions for MR imaging and a catalytic antioxidant for therapy. ${ }^{2}$ In healthy volunteers, MnDPDP raised the signal intensity (SI) in the exocrine glands in the head and neck, chorioid plexus, and anterior pituitary gland but not beyond the BBB. The observations are important because the infusion time ( $<10$ minutes $)$ and dose $(5 \mu \mathrm{mol} / \mathrm{kg})$ have been standard in MR imaging of the liver and pancreas. Thus, the study confirms that a brief infusion of 1 diagnostic dose does not cause MR imaging contrast enhancement in the brains of humans with an intact $\mathrm{BBB}$ and normal liver function.

Concerning future brain $\mathrm{Mn}$ uptake studies, we find it relevant to address a patient who received MnDPDP in a total dose of $140 \mu \mathrm{mol} / \mathrm{kg}$ during 8 months. ${ }^{3}$ In this patient with terminal cancer of the colon, MnDPDP $(10 \mu \mathrm{mol} / \mathrm{kg})$ was administered for the protection of normal tissue during 14 cycles of chemotherapy with anticancer agents (oxaliplatin and 5-fluorouracil). The regimen was well-tolerated without the adverse effects of chemotherapy, and there was a notable relief of pain. At end of treatment, mild Parkinson-like symptoms occurred, and brain MR imaging (Fig 1), images not previously disclosed, showed high SI in the basal ganglia (caudate nucleus, globus pallidus, putamen, and thalamus). However, the SI was also high in the corpus callosum, mesencephalon, brain stem, cerebellum, and anterior pituitary gland. In this patient, the first to receive MnDPDP for therapy, an apparent palliation was at the cost of widespread brain deposition of $\mathrm{Mn}$ caused by a far-too-high total dose of MnDPDP, advanced liver failure, and, possibly, a BBB weakened by disease or treatment.

Most interesting, SI was maximal in the dentate nucleus and globus pallidus, sites also noted for deposition of gadolinium (Gd) ions released from linear chelates. ${ }^{4}$ This finding may indicate a mutual, possibly calcium-related, pathway for storage of $\mathrm{Mn}$ and $\mathrm{Gd}$ adducts in the brain.

\footnotetext{
- Indicates open access to non-subscribers at www.ajnr.org
}

http://dx.doi.org/10.3174/ajnr.A6347
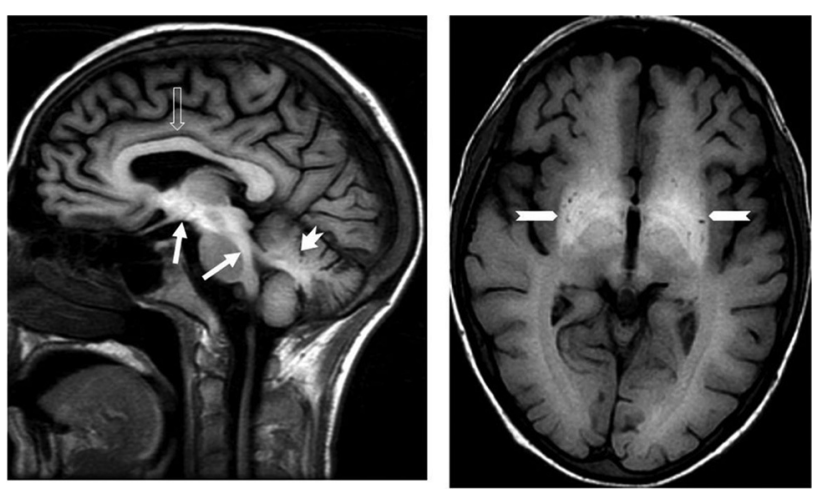

FIG 1. Sagittal (T1-weighted-FLAIR) and axial (T1-weighted spin-echo) images show high SI reflecting $\mathrm{Mn}$ deposition in the corpus callosum (open arrow), mesencephalon, crus cerebri, dorsal brain stem, medulla oblongata (white arrows), cerebellum (dentate nucleus) (short white arrow with cut), and basal ganglia (globus pallidus and putamen) (long arrows with cut).

\section{REFERENCES}

1. Sudarshana DM, Nair G, Dewey B, et al. Manganese-enhanced MRI of the brain in healthy volunteers. AJNR Am J Neuroradiol 2019;40:130916 CrossRef Medline

2. Karlsson JO, Ignarro LJ, Lundström I, et al. Calmangafodipir $\left[\mathrm{Ca}_{4} \mathbf{M n}\right.$ (DPDP)5], mangafodipir (MnDPDP) and MnPLED with special reference to their SOD mimetic and therapeutic properties. Drug Discov Today 2015;20:411-21 CrossRef Medline

3. Yri OE, Vig J, Hegstad E, et al. Mangafodipir as cytoprotective adjunct to chemotherapy: a case report. Acta Oncol 2009;48:633-35 CrossRef Medline

4. Kanda T, Nakai Y, Hagiwara A, et al. Distribution and chemical forms of gadolinium in the brain: a review. Br J Radiol 2017;90:20170115 CrossRef Medline

$$
\begin{array}{r}
\text { OV. Blomlie } \\
\text { R. Sivanandan } \\
\text { Department of Radiology } \\
\text { Innlandet Trust Hospital, Gjøvik Hospital } \\
\text { Gjøvik, Norway } \\
\text { OP. Jynge } \\
\text { Department of Radiology } \\
\text { Norwegian University of Science and Technology } \\
\text { Gjøvik, Norway } \\
\text { Trondheim, Norway } \\
\text { University of Linkøping } \\
\text { Linkøping, Sweden }
\end{array}
$$

